\title{
Penyuluhan Kesehatan Konsumsi Buah dan Sayur di Rw 003 Kelurahan Benda Baru Pamulang Sebagai Upaya Pencegahan Tuberkolosis
}

\section{Health Education of Fruit and Vegetable Consumption In Rw 003 Benda Baru Pamulang As An Effort To Prevent Tubercolosis}

\author{
${ }^{1)}$ Fini Fajrini, ${ }^{2)}$ Ade Akhmad Bukhori, ${ }^{3)}$ Adzhani Khanza Ramadhani, ${ }^{4)}$ Fara Sulti Nadya, \\ ${ }^{5)}$ Hani Nur Syarifah, ${ }^{6}$ Hani Nur Syarifah, ${ }^{7}$ Isna Indah Sari, ${ }^{8)}$ Maulida Fitria \\ ${ }^{1,2,3)}$ Fakultas Kesehatan Masyarakat, Universitas Muhammadiyah Jakarta \\ Alamat : Jl. K. H. Ahmad Dahlan, Cireundeu, Ciputat \\ Email : $\underline{\text { fffajrini@yahoo.com }}$
}

\begin{abstract}
Abstrak
Di Indonesia pemberantasan penyakit tuberkulosis telah dimulai sejak tahun 1950 dan sesuai rekomendasi WHO sejak tahun 1986 regimen pengobatan yang semula 12 bulan diganti dengan pengobatan selama 6-9 bulan. Pemerintah sudah sangat serius memperhatikan masalah TBC, dengan memberikan bantuan berupa pemberian obat TBC secara gratis. Namun faktanya, efektifitas pengobatan yang dilakukan oleh penderita TBC masih rendah. Tingkat kesembuhan penderita tuberkulosis adalah sebesar 85,30\%, dengan tingkat kesukaan buah sebanyak 84\%. Namun intensitas responden dalam mengkonsumsi buah hanya sebesar $68 \%$ dan tingkat konsumsi buah hanya sebesar 65,30\%, serta tingkat keteraturan konsumsi buah saat menderita tuberkulosis hanya sebesar 67,30\%. Berdasarkan hasil Musyawarah Masyarakat Desa, masyarakat sepakat untuk memilih TBC untuk menjadi acuan intervensi program. Pengabdian Masyarakat yang dilakukan dalam bentuk penyuluhan ini mengangkat tema "Ayo Konsumsi Buah dan Sayur untuk Putus Tali Penularan TBC." Penyuluhan kesehatan ini dilaksanakan pada hari Sabtu, 15 Februari 2020 di Mushola AR-Rahman RT 04 RW 003. Dihadiri oleh 30 orang terdiri dari lapisan masyarakat dari RW 003 Kelurahan Benda Baru. Berdasarkan hasil perhitungan pre-test dan post-test, didapatkan bahwa ada peningkatan pengetahuan masyarakat terkait manfaat buah dan sayur untuk penyakit Tuberkolosis antara sebelum dan setelah diberikan penyuluhan. Disarankan agar kebiasaan maka buah dan sayur bisa menjadi kebiasaan di tengan masyarakat.
\end{abstract}

Kata Kunci : Penyuluhan, Konsumsi Buah dan Sayur, Tuberkolosis.

\begin{abstract}
In Indonesia the eradication of tuberculosis has been started since 1950 and according to WHO recommendations since 1986 the treatment regimen that was originally 12 months replaced with treatment for 6-9 months. The government has been very serious about paying attention to the TBC problem, by providing assistance in the form of giving free TBC medicines. But in fact, the effectiveness of treatment carried out by people with TBC is still low. It was found that the cure rate of tuberculosis patients was $85.30 \%$, with a fruit preference rate of $84 \%$. But the intensity of respondents in consuming fruit was only $68 \%$ and the level of fruit consumption was only $65.30 \%$, and the level of regularity of fruit consumption when suffering from tuberculosis was only $67.30 \%$. Based on the results of the Village Community Conference, the community agreed to choose $T B C$ as a reference for program intervention. Community Service is carried out in the form of counseling with the theme "Let's Eat Fruits and Vegetables to Break the Rope of TBC Transmission." This health education was held on Saturday, February 15, 2020 at Mushola AR-Rahman RT 04 RW 003. Attended by 30 people consisting of people from RW 003 Benda Baru Village. Based on the results of the pre-test and post-test calculations, it was found that there was an increase in community knowledge related to the benefits of fruits and vegetables for tuberculosis between before and after counseling. It is suggested that the habbit of fruit and vagetables can become a habit among the people.
\end{abstract}

Keyword : Counseling, Consumption of Fruits and Vegetables, Tuberculosis 
Volume. 2 No. 1 tahun 2020

Mei 2021 - November 2021
ISSN (online): 2722-2055

https://jurnal.umj.ac.id/index.php/AS-
AS-SYIFA: Jurnal Pengabdian dan Pemberdayaan Kesehatan

Masyarakat

\section{Pendahuluan}

Tuberkulosis adalah suatu penyakit infeksi yang disebabkan oleh Mycobakterium tuberkulosis dan bersifat menular (Christian, 2009; Storla, 2009). WHO menyatakan bahwa sepertiga penduduk dunia telah terinfeksi kuman tuberkulosis. Setiap detik ada satu orang yang terinfeksi tuberkulosis. Di Indonesia pemberantasan penyakit tuberkulosis telah dimulai sejak tahun 1950 dan sesuai rekomendasi WHO sejak tahun 1986 regimen pengobatan yang semula 12 bulan diganti dengan pengobatan selama 6-9 bulan. Strategi pengobatan ini disebut DOTS (Directly Observed Treatment Short Course Chemotherapy). Cakupan pengobatan dengan strategi DOTS tahun 2000 dengan perhitungan populasi 26 juta, baru mencapai $28 \%$. Risiko perkembangan infeksi TBC menjadi sakit TBC meningkat akibat penurunan sistem imun oleh Human Immunodeficiency Virus (HIV), diabetes melitus (DM), konsumsi alkohol, malnutrisi, merokok (Narasimhan P, dkk.2013). Berdasarkan Global Report WHO tahun 2013 dalam Kementrian Kesehatan RI (2015) jumlah pasien TBC dengan HIV positif di Indonesia meningkat dari 3,3\% pada tahun 2012 menjadi 7,5\% pada tahun 2013 (KEMENKES.2015). Diabetes dan TBC Paru di Poliklinik Penyakit Dalam RSUP Dr. M. Djamil Padang didapatkan sebanyak 4,5\% (Nazulis RA, 2011). Di RSCM tahun 2010 pasien yang memiliki riwayat mengonsumsi alkohol 37\% menderita TBC paru (Erick, 2012).

Penderita tuberkulosis paru BTA (+) dapat menularkan pada orang sekelilingnya, terutama yang melakukan kontak erat. Setiap penderita tuberculosis paru BTA (+) dapat menularkan pada 10-15 orang per tahun. Daya penularan dari seorang penderita tuberculosis paru BTA (+) ditentukan oleh banyak bakteri yang dikeluarkan dari paru-paru. Kondisi lingkungan dalam rumah yang tidak memenuhi syarat menjadi media penularan penyakit tuberculosis paru. Faktor lingkungan dalam rumah yang secara statistik berhubungan bermakna dengan kejadian penyakit tuberkulosis paru adalah ventilasi kamar, kelembaban kamar, sinar matahari, dan kepadatan hunian kamar (Versitaria HU, 2011).

Berdasarkan penyebab utama banyaknya penderita tuberkulosis di Kabupaten Ciamis yaitu karena malnutrisi. Selain itu menurut Miranti Gutawa, Kepala Instalasi Gizi RSHS Kota Bandung yang menyatakan risiko komplikasi termasuk kematian pada penderita TBC dipengaruhi oleh status gizi secara individual. Namun status gizi dan utilisasi atau penggunaan zat gizi itu sendiri menjadi terganggu akibat adanya infeksi. Sesak nafas, batuk, sakit dada, dan penurunan nafsu makan pada penderita TBC menambah terjadinya asupan makan dan minum pasien yang rendah dari kebutuhan. Sementara dengan adanya infeksi, kebutuhan zat gizi menjadi meningkat karena tubuh memerlukan energi untuk kegiatan dasar tubuh dan melawan penyakit itu sendiri. Malnutrisi dapat diatasi dengan pemenuhan gizi seimbang. Salah satunya dengan mengkonsumsi buah dan sayur dapat memenuhi kebutuhan nutrisi harian tersebut.

Pemerintah sudah sangat serius memperhatikan masalah TBC, dengan memberikan bantuan berupa pemberian obat TBC secara gratis. Namun faktanya, efektifitas pengobatan yang dilakukan oleh penderita TBC masih rendah. Hal ini menjadi perhatian khusus untuk mengetahui efektifitas konsumsi buah dan sayur terhadap tingkat penyembuhan TBC. Berdasarkan penelitian Yustiaji, dkk, 2016 didapatkan bahwa tingkat kesembuhan penderita tuberkulosis adalah sebesar $85,30 \%$, dengan tingkat kesukaan buah sebanyak $84 \%$. Namun intensitas responden dalam mengkonsumsi buah hanya sebesar $68 \%$ dan tingkat konsumsi buah hanya sebesar $65,30 \%$, serta tingkat keteraturan konsumsi buah saat menderita tuberkulosis hanya sebesar $67,30 \%$. Hal ini menjadi perhatian serius dikarenakan tingkat kepatuhan dalam mengkonsumsi obat sebesar 92,66\%. Semestinya tingkat kesembuhan penderita tuberkulosis minimal dengan tingkat kepatuhan dalam mengkonsumsi obat itu sebanding. Hal tersebut menunjukkan bahwa konsumsi buah berpengaruh pada tingkat kesembuhan tuberkulosi. 
ISSN (online): 2722-2055 https://jurnal.umj.ac.id/index.php/ASSYIFA
AS-SYIFA: Jurnal Pengabdian dan Pemberdayaan Kesehatan Masyarakat

Berdasarkan hasil analisis saat dilakukan observasi di wilayah kerja Puskesmas Benda Baru didapatkan hasil bahwa Maage merupakan penyakit dengan angka kejadian tertinggi namun berdasarkan hasil data sekunder didapatkan TBC merupakan penyakit dengan kasus terbanyak. Sehingga ketika melakukan Musyawarah Masyarakat Desa, masyarakat sepakat untuk memilih TBC untuk menjadi acuan intervensi program. Oleh karena itu, diadakan intervensi kinerja penyuluhan konsumsi buah dan sayur kepada masyarakat sebagai alternative pemecahan masalah TBC. Diharapkan kegiatan intervensi ini dapat meningkatkan wawasan masyarakat mengenai penyakit Tuberkulosis serta meningkatkan imunitas masyarakat melalui konsisten konsumsi buah dan sayur setiap harinya.

\section{Metode}

Pengabdian masyarakat ini dilakukan dalam bentuk penyuluhan konsumsi buah dan sayur untuk Penderita TBC dan meningkatkan imunitas masyarakat di sekitarnya. Kegiatan penyuluhan dilaksanakan dengan metode ceramah serta pemberian pre-test dan post-test dalam bentuk kuesioner untuk menilai sejauh mana pemahaman masyarakat akan materi yang disampaikan serta digunakan sebagai indikator keberhasilan program. Media yang digunakan dalam kegiatan ini berupa slide presentasi dari power point, serta soal pre-test dan post-test. Kegiatan penyuluhan dilaksanakan di RW 003 RT 04 Kelurahan Benda Baru, Kecamatan Pamulang, Kota Tangerang Selatan pada Hari Sabtu, 15 Februari 2020 bertempat di Mushola ARRahman RT 04 dengan jumlah 30 peserta yang terdiri dari ibu-ibu pengajian.

\section{Hasil dan Pembahasan}

Kegiatan penyuluhan kesehatan terkait konsumsi buah dan sayur dilakukan di RW 003 Kelurahan Benda Baru, Kecamatan Pamulang, Kota Tangerang Selatan. Kegiatan penyuluhan ini dilaksanakan pada Hari Sabtu, 15 Februari 2020 bertempat di Mushola ARRahman RT 04 dan dimulai pada pukul 13.30WIB - 16.30 WIB. Kegiatan penyuluhan kesehatan ini mengangkat tema "Ayo Konsumsi Buah dan Sayur Untuk Putus Tali Penularan TBC”. Kegiatan ini dihadiri oleh beberapa lapisan masyarakat dari RW 003 Kelurahan Benda Baru.

Kegiatan penyuluhan diawali dengan pembukaan oleh pembawa acara, dilanjutkan dengan pembagian soal pre-test yang terdiri dari 13 pertanyaan seputar pengetahuan penyakit TBC dan kurangnya Konsumsi buah dan sayur sebagai faktor mudahnya tertular TBC. Masyarakat diberikan waktu sekitar 10 menit untuk mengisi soal pre-test dengan menggunakan pulpen yang telah disediakan. Setelah mengisi soal pre-test, disampaikan materi terkait penyakit Tuberkolosismulai dari definisi, tanda dan gejala, faktor,dan pengetahuan tentang konsumsi buah dan sayur yang baik untuk mencegah TBC. Penyampaian materi dilakukan sekitar 30 menit. Setelah selesai memaparkan materi, masyarakat kembali diberikan kuesioner berisi post-test yang berisi 13 pertanyaan yang sama dengan soal pre-test untuk mengukur sejauh mana tingkat pemahaman masyarakat terkait materi yang baru saja disampaikan yang di isi 30 peserta.

Selain memberikan edukasi melalui penyuluhan, kami membuka sesi tanya jawab dimana warga bebas bertanya mengenai materi yang sudah disampaikan dan soal yang telah dikerjakan. Tujuan diadakannya sesi tanya jawab agar warga lebih paham dan mengerti mengenai bahayanya penyakit menular TBC dan diharapkan setelah kegiatan ini dapat membiasakan diri dan keluarganya untuk mengkonsumsi buah dan sayur untuk meningkatkan imunitas sehingga dapat mencegah atau mengurangi penyakit TBC. 


\section{Analisis Pencapaian Tujuan Analisis SWOT}

\begin{tabular}{|l|l|l|l|l|l|}
\hline No & Nama Kegiatan & Strength & Weakness & Opportunity & Threat \\
\hline & Penyuluhan tentang & Materi yang & Mahasiswa & Adanya & Adanya kendala \\
& Konsumsi buah dan & disampaikan & belum & dukungan dari & Cuaca yang \\
& sayur untuk & menarik dan & memahami & berbagai pihak & mengakibatkan \\
& mencegah & menggunakan & semua sifat & seperti Ketua & tertundanya \\
& Tuberkolosis & bahasa yang & masyarakat & RW 003,ketua & waktu \\
& mudah pemaparan \\
& dimengerti & & RT 04 beserta & pemat \\
& sehingga & & kader setempat & (Presentasi) \\
& masyarakat Pembina & \\
& berpartisipasi & & Lapangan & \\
& aktif dalam & & Puskesmas & \\
& penyuluhan & & Benda Baru & \\
& & & & \\
\hline
\end{tabular}

\section{Perbandingan Data Sebelum dan Sesudah Intervensi}

Pada kegiatan penyuluhan kesehatan ini didapatkan hasil bahwa sebanyak 30 warga hadir dalam kegiatan. Metode yang digunakan ialah ceramah interaktif dengan menggunakan media slide dari power point. Semua warga yang hadir mengikuti pelaksanaan pre-test dan post-test. Masyarakat yang hadir dalam kegiatan sangat antusias serta responsif, hal itu dapat dilihat dari adanya respon serta beberapa pertanyaan yang diajukan. Kegiatan ini terlaksana sesuai dengan hari yang telah ditentukan sebelumnya. Analisis hasil pre-test dan post-test menggunakan sps

Sebelum Penyuluhan

\begin{tabular}{lcc}
\hline \multicolumn{1}{c}{ Pengetahuan } & Jumlah & $\begin{array}{c}\text { Persentase } \\
(\%)\end{array}$ \\
\hline Baik & & 33,3 \\
Kurang & 10 & 66,7 \\
\hline Jumlah & 20 & $\mathbf{1 0 0}$ \\
\hline
\end{tabular}

Sesudah Penyuluhan

\begin{tabular}{lcc}
\hline \multicolumn{1}{c}{ Pengetahuan } & Jumlah & $\begin{array}{c}\text { Persentase } \\
(\%)\end{array}$ \\
\hline Baik & & 43,3 \\
Kurang & 13 & 56,7 \\
\hline Jumlah & 17 & 100 \\
\hline
\end{tabular}

Dengan pelaksanaan intervensi ini diharapkan masyarakat memahami tentang definisi penyakit TBC, tanda dan gejala, faktor risiko yang menyebabkan TBC khususnya kurangnya konsumsi buah dan sayur, cara pencegahan penyakit TBC dari memakan buah dan sayur sesuai rekomendasi yang baik untuk meningkatkan antibodi, serta dampak jika tidak 
melakukan pola hidup sehat dan lain-lain. Hal ini dapat dilihat dari hasil pengisian soal pretest dan post-test. Berdasarkan hasil perhitungan, didapatkan bahwa ada peningkatan pengetahuan masyarakat terkait penyakit TBC antara sebelum dan setelah diberikan penyuluhan.
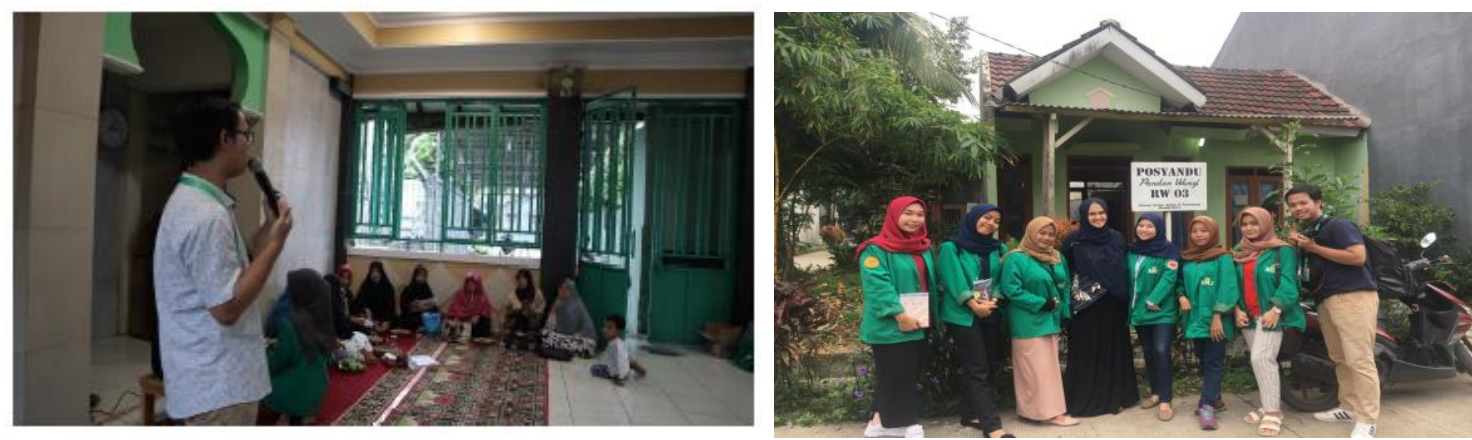

\section{Kesimpulan Dan Saran}

\section{a. Kesimpulan}

Kegiatan penyuluhan kesehatan tentang konsumsi buah dan sayur dengan tema "Ayo Konsumsi Buah dan Sayur untuk Putus Tali Penularan TBC." ini berjalan dengan lancar. Peserta antusias dalam mengikuti setiap tahapan acara, dan bisa kooperatif. Hasil pre-test dan pos-test menunjukkan ada peningkatan yang signifikan terhadap pengetahuan peserta mengenai penyakit Tuberkolosis serta pengetahuan konsumsi buah dan sayur yang baik untuk mencegah TBC. Sehingga outcome yang diharapkan dapat tercapai dengan sangat baik.

\section{b. Saran}

Diharapkan pengabdian masyarakat ini dapat menjadi masukan bagi pihak Puskesmas selaku penyelenggara kesehatan dalam meningkatkan kesehatan masyarakat dengan meningkatkan kesadaran masyarakat untuk hidup sehat. Serta diharapkan tokoh masyarakat beserta seluruh masyarakat Benda Baru dapat lebih antusias dan dapat semakin sadar untuk hidup sehat dan konsisten menjakankan program yang telah dibangun bersama. Setidaknya setiap orang dapat menjalankan memakan sayur dan buah minimal 1 buah 1 sayur setiap hari agar terhindar dari penyakit TBC. Karena konsumsi buah dan sayur dapat meningkatkan antibody dalam tubuh agar terhindar dari tertularnya penyakit TBC. Sehingga derajat kesehatan masyarakat Benda Baru dapat semakin meningkat dan jauh dari penyakit menular khususnya Tuberkolosis.

\section{Ucapan Terima Kasih}

Ucapan terima kasih kami sampaikan kepada Puskesmas dan warga di RW 003 Kelurahan Benda Baru Kecamatan Pamulang Kota Tangerang Selatan yang telah memberikan kesempatan kepada kami untuk melakukan pengabdian masyarakat dalam upaya meningkatkan kesadaran warga agar lebih semangat menciptakan kebiasaan hidup yang sehat.

\section{Daftar Pustaka}

Christian, W., Gomes, V.F. Rabna, P., Gustafson, P., Aaby, P., Lisse, I.M, Andersen, P.L., Glerup, H. \& Sodemann, M. 2009. Vitamin D as Supplementary Treatment for Tuberculosis. American Journal of Respiratory and Critical Care Medicine, 179(9): 843-850 

SYIFA

AS-SYIFA: Jurnal Pengabdian dan Pemberdayaan Kesehatan Masyarakat

Erick. Hubungan antara konsumsi alkohol dengan prevalensi tuberkulosis paru pada pasien diabetes mellitus tipe 2 di rumah sakit Cipto Mangunkusumo tahun 2010. Jakarta: Fakultas Kedokteran Universitas Indonesia (FKUI); 2012.

Kementrian Kesehatan RI. Penanggulangan tuberkulosis terpadu- TBC Indonesia. Kementrian Kesehatan RI; 2015.

Miranti Gutawa, 2013. Konsep “Beter Hospital Food”. Pelatihan Pelayanan Gizi, Rumah Sakir DPD AsDI Jabar. Bandung

Narasimhan P, Wood J, MacIntyree CR, Mathai D. Review article: risk factors for tuberculosis. Hindawi Publishing Corporation. Pulmonary Medicine; 2013.

Nazulis RA. Drug related problem pada pasien diabetes melitus tipe 2 dengan tuberkulosis paru di bangsal penyakit dalam dan poliklinik RSUP.Dr.M.Djamil Padang (artikel penelitian). Padang: Fakultas Kedokteran Universitas Andalas; 2011.

Versitaria HU, Kusnoputranto H. Tuberkulosis Paru di Palembang, Sumatera Selatan. Kesmas: National Public Health Journal. 2011;5(5):234-40.

WHO.Global Tuberculosis Control: WHO Report 2013. Geneva 2013

Yustiaji,Luqman dll.2016. Efektifitas Konsumsi Buah Dan Sayur Terhadap Tingkat Penyembuhan TBC.Ciamis.Academia.edu

https://www.academia.edu/37588753/Efektifitas_Konsumsi_Buah_Dan_Sayur_Terhadap_Ti ngkat_Penyembuhan_TBC 